$\stackrel{\odot}{I I}$

\title{
SZARE BLOKI Z WIELKIEJ PŁYTY PRZYTŁACZAJĄ?' BLOKOWISKA W POZANAUKOWYM DYSKURSIE PUBLICZNYM
}

\begin{abstract}
Edyta Tomczyk, Szare bloki z wielkiej płyty przytłaczaja? Blokowiska w pozanaukowym dyskursie publicznym [Are grey prefabricated blocks overwhelming? Bleak apartment blocks in nonscientific public discourse] edited by M. Nowak "ICzłowiek i Społeczeństwo" vol. XLVIII: Kuchnia badań miejskich. Studia na temat praktyki empirycznej badaczy miasta [A backstage of urban research. Studies on the empirical practices of city research scientists], Poznań 2019, pp. 91-105, Adam Mickiewicz University. ISSN 0239-3271.
\end{abstract}

The article presents the results of a study on the latest non-scientific public discourse on Warsaw large housing estates, with particular emphasis on architectural and urban issues, based on the analysis of press articles from a popular daily regional paper, "Gazeta Stołeczna", blogs devoted to the city and hip-hop pieces written by Warsaw rappers. Discourse analysis included the identification of the discourse participants, i.e. who is talking to whom?; discourse content analysis, i.e. what is said?; and, finally, determination of the type of discourse and the role of language i.e. how it is said? The article consists of two parts. In the first methodological section a general view over discourse analysis as a tool for conducting interdisciplinary research and a short review of Polish works on discourse in the context of urban research are discussed. The second part of the paper is devoted to the results and conclusions of the study.

Edyta Tomczyk, Instytut Rozwoju Miast i Regionów, ul. Targowa 45, 03-728 Warszawa, etomczyk@ irm.krakow.pl

${ }^{1}$ W tytule wykorzystano cytat z: Bukłaha, 2017: 12. 


\section{Wprowadzenie}

Po zmianie systemu politycznego w Polsce wielkie osiedla mieszkaniowe (WOM; określenie za: Szafrańska, 2016)² przestały być atrakcyjnym miejscem do mieszkania. Stały się niebezpieczne, kojarzyły się z przegranymi transformacji (np. Chomątowska, 2018: 392-403, 420-445 i in.). Ci, którym się udało, czym prędzej przeprowadzali się do domów pod miastem lub na nowe osiedla grodzone. Jeszcze kilka lat temu w pozanaukowym dyskursie, głównie prasowym, osiedla wielkopłytowe oceniano wyłącznie krytycznie, a nawet przewidywano, że z czasem znikną z polskiego krajobrazu.

Jednak trzydzieści lat po upadku PRL w blokowiskach nadal mieszka ok. 20\% mieszkańców Polski, czyli co najmniej 7 milionów ludzi (Słodczyk, 2012), a nawet według niektórych badaczy ponad 8 milionów (Węcławowicz, 2007). Na razie więc można sądzić - także w świetle przeprowadzonych ostatnio przez Instytut Techniki Budowlanej (2019) badań stanu technicznego prefabrykatów w blokach - że przyszłość tych osiedli nie jest zagrożona.

Nierozstrzygnięte natomiast pozostaje pytanie o współczesne waloryzowanie blokowisk. Czy po kilkudziesięciu latach krytycznych ocen nadal powszechnie uważa się, że w „«blokowisku» dźwięczy wszystko co złe: monotonia i przytłaczająca skala architektury, której modernistycznego języka nie uczono w PRL-owskich szkołach, anonimowość, przestępczość (zwykle z dopiskiem «nieletnich»), brudne klatki schodowe, szarość” (Chomątowska, 2017: 2)? Zbadanie obrazu blokowisk w pozanaukowym dyskursie publicznym stało się celem przeprowadzonego przeze mnie w 2018 r. badania. Niniejszy artykuł, stanowiący jego podsumowanie, składa się z części metodologicznej dotyczącej analizy dyskursu jako narzędzia do badania zjawisk o interdyscyplinarnym charakterze, a także z krótkiego przeglądu polskich publikacji, w których metodę tę zastosowano do szeroko rozumianych badań miejskich. W drugiej części tekstu została przedstawiona metodyka samego badania, jego cele i zakres, a także rezultaty i wnioski z przeprowadzonej analizy.

${ }^{2}$ Na potrzeby badania przyjęto następującą definicję (za: Szafrańska, 2016: 36-37): „wielkie osiedla mieszkaniowe to wyodrębnione przestrzennie obszary zunifikowanej zabudowy wielorodzinnej wykonanej w prefabrykowanej technologii, liczące ponad 5 tys. mieszkań, powstałe w II połowie XX wieku, których budowa finansowana była ze środków publicznych”. Tak więc cechami dystynktywnymi WOM są: wielka skala, jednorodność zabudowy i technologia wykonania, wyodrębnienie przestrzenne, okres budowy i publiczne źródło finansowania. 


\section{Ramy metodologiczne badania i literatura przedmiotu}

Przedstawienie metodyki badania oraz wyników pracy badawczej trzeba poprzedzić choćby skrótowym omówieniem szerszych ram metodologicznych, w które się ono wpisuje, a które dotyczą tak pojemnego terminu, jak (krytyczna) analiza dyskursu. Ze względu na ograniczenia niniejszego tekstu w prowadzonych tu rozważaniach pomijam kwestię samego terminu „dyskurs”, który wobec wielości różnorodnych definicji mógłby stać się tematem oddzielnego opracowania (szerzej o tym zob. np. Synowiec, 2013). Na potrzeby badania przyjęto (za: Fairclough i Duszak, 2008: 7) ogólne założenie, że dyskurs oznacza „tekst w kontekście”. Stąd też w tego rodzaju analizie bierze się pod uwagę „również szerszy kontekst jego powstania, rozpowszechniania i odbioru” (Nijakowski, 2006: 17). Dla porządku warto tylko dodać, że w polskiej literaturze, w przeciwieństwie do np. anglosaskiej czy francuskiej, termin ten w takim rozumieniu, choć pojawił się później, jest obecnie jednak powszechnie stosowany.

Rozwijająca się od lat dziewięćdziesiątych XX w. krytyczna analiza dyskursu (KAD; critical discourse analysis (van Dijk, 1993)) wyewoluowała z badań prowadzonych na polu lingwistyki, w ramach socjolingwistyki (Gumperz, 1982; Schiffrin, 1994) i analizy dyskursu (np. Sinclair i Coultard, 1975), które zajmowały się użyciem języka w kontekście społecznym. Kolejnym krokiem w kierunku KAD był rozwój lingwistyki systemowo-funkcjonalnej (LSF; systemic functional linguistics (np. Halliday, 1978)) i wreszcie wywodzącej się z niej lingwistyki krytycznej (critical linguistics (np. Fowler, Hodge, Kress i Trew, 1979; Fairclough, 1989; 1992)).

Drugą dziedziną nauki, która przyczyniła się do powstania krytycznej analizy dyskursu, są nauki społeczne w tych jej nurtach, które zajmują się ideologią i teorią władzy, ważnym kontekstem dla KAD. W tym nurcie wiodącą rolę odegrał Michel Foucault (np. 1971), który pchnął nauki społeczne w stronę dyskursu rozumianego jako system wiedzy i władzy. Innym ważnym źródłem inspiracji były teksty z kręgu zachodniego marksizmu takich badaczy kwestii hegemonii i ideologii, jak Antonio Gramsci czy Louis Althusser, które stanowiły inspirację dla późniejszej postrukturalistycznej teorii dyskursu wypracowanej przez Ernesta Laclau i Chantal Mouffe (2007).

Analiza dyskursu, w różnych jej aspektach: deskryptywnym (analiza dyskursu, AD; discourse analysis) i krytycznym (KAD), ma więc od samego początku interdyscyplinarny charakter, będąc metodą badań dyskursywnych 
różnych dziedzin naukowych (Graham, 2008). Cechują ją różnorodne podejścia zarówno do samego dyskursu, jak i procesów społecznych, przy czym jej istotą jest relacja między dyskursem a innymi procesami społecznymi (Fairclough i Duszak, 2008). Trzeba dodać, że poszczególne badania mogą, w zależności od przedmiotu, czerpać z innych teorii naukowych (w przypadku tematyki miejskiej np. z geografii społecznej, antropologii kulturowej, urbanistyki i architektury, socjologii). Dlatego trzeba wybrać lub dopasować zasady metodologiczne do przedmiotu badania, a więc niejako sprofilować analizę pod kątem konkretnego badania. Ze względu na różne zagadnienia badawcze i założenia metodologiczne niektórzy badacze zwracają uwagę na eklektyczny charakter tej metody (Chilton, 2008). Pomimo dużego zróżnicowania tak w przedmiocie badań, jak i wyborze czy stworzeniu własnej odmiany metod badawczych Fairclough i Duszak (2008) wyróżniają następujące cechy wspólne wszystkich badań w ramach analizy dyskursu w jej wymiarze krytycznym: „KAD zajmuje się procesami i problemami społecznymi” (Fairclough i Duszak, 2008: 15); „dyskurs jest kluczowym czynnikiem w społecznej konstrukcji życia społecznego" (Fairclough i Duszak, 2008: 16); ,dyskurs jest ważnym elementem władzy” (Fairclough i Duszak, 2008: 17); „krytyczna analiza dyskursu zawiera element szczegółowej analizy tekstu” (Fairclough i Duszak, 2008: 18).

Przechodząc do polskich publikacji z dziedziny zagadnień miejskich posiłkujących się analizą dyskursu, należy zauważyć, że KAD czy AD częściej są wykorzystywane w pracach z zakresu gender studies, mniejszości narodowych, tożsamości narodowej i etnicznej, rzadziej natomiast do prowadzenia badań o mieście. Zidentyfikowane prace poświęcone zastosowaniu analizy dyskursu do badań nad miastem, przy ich niewątpliwej interdyscyplinarności, można podzielić ze względu na główną dziedzinę, która kształtuje ramy badania, w tym jego metodologię, korpus badawczy i cel badania. Analizę dyskursu odnoszącą się do tematyki miejskiej można więc napotkać w pracach geograficznych, kulturoznawczych, antropologicznych i wreszcie socjologicznych.

Wśród najnowszych prac, w których analiza dyskursu została wykorzystana do interdyscyplinarnego projektu z zakresu geografii społeczno-ekonomicznej, geografii przestrzennej, ale i nauk społecznych, wyróżnia się trwające jeszcze badanie „Współdzielenie przestrzeni miejskiej. Koncepcje dobra wspólnego w polskich miastach po socjalizmie” zrealizowane przez dr Maję Grabkowską, którego częściowe rezultaty zostały już opublikowane w formie artykułów (Grabkowska, 2017; 2018). Podejście łączące różne metody badawcze objęło m.in. analizę dyskursu dobra wspólnego 
w kontekście przestrzeni miejskiej wyłaniającego się z dokumentów strategicznych i prasy. O założeniach metodologicznych autorka pisze następująco: „[przeprowadzono] analizę przyjętego języka, a zwłaszcza doboru słów, retoryki, konwencji i wzorców językowych [...]. Metoda ta umożliwi [...] ukazanie teorii dobra wspólnego na tle praktyki społecznej, a ponadto pozwoli na zbadanie, w jaki sposób pojęcie to używane jest względem przestrzeni miejskiej, jak też na porównanie różnych perspektyw i narracji” (Grabkowska, 2017: 45-46).

Wśród innych badań w tym nurcie warto odnotować pracę Janusza Lipińskiego (2015) na temat analizy dyskursu metropolitalnego Trójmiasta na podstawie dokumentów administracyjnych i stosowanego w nich nazewnictwa. Na podobnych założeniach oparta jest też praca Jarosława Jańczaka (2013) poświęcona analizie oficjalnego dyskursu integracyjnego przygranicznych miast bliźniaczych, przeprowadzona jednak na podstawie wywiadów semistrukturyzowanych z przedstawicielami administracji publicznej.

Z kolei spośród tekstów wyrosłych ze sfery kulturoznawczej warto wymienić prace Beaty Dudy (2015; 2018), które stawiały sobie za cel stworzenie kategorii dyskursu miejskiego, a w ich polu badawczym znalazły się dyskursy związane z Warszawą pochodzące z przewodników turystycznych, spacerowników, blogów podróżniczych, wypowiedzi urzędników miejskich i mieszkańców. Celem była analiza obrazu miasta, uchwycenie złożoności semantycznej i uwypuklenie różnych, stojących w opozycji do siebie punktów widzenia turystów i mieszkańców. Podsumowaniem badania była próba stworzenia teoretycznego modelu dyskursu miejskiego traktowanego jako kategoria transdyskursywna, w której wyróżniono wiedzę o mieście generującą znaczenia, podmioty dyskursu (kategorię turysty, mieszkańca, włóczęgi, gracza) i źródła dyskursu, wpisane w szeroki kontekst kulturowy miasta.

Wśród innych badań w tym nurcie warto odnotować pracę Kamilli Biskupskiej (2018) dotyczącą doświadczania (oswajania) przestrzeni miejskiej przez powojenną ludność napływową Wrocławia. Analizie poddano pamiętniki mieszkańców spisane w latach sześćdziesiątych ubiegłego wieku na konkurs, a celem opracowania stało się ukazanie relacji między materialnym otoczeniem a pozytywnymi lub negatywnymi emocjami, jakie budzi ono w mieszkańcach.

Podobnym tropem idzie Dobrosława Korczyńska-Partyka (2018) analizująca relację między pamięcią a przestrzenią miejską za pomocą analizy dyskursów polskiej literatury powstałej po roku 1989. Badaczka stawia sobie za cel odczytanie strategii narracyjnych, które prowadzą do ujawnienia określonych wzorów i schematów narracji pamięciowych, wpływających 
z kolei na sposób postrzegania rzeczywistości kulturowej i tworzenie się relacji społecznych.

Innym, szczególnie ciekawym dla mnie wątkiem badań nad dyskursem poświęconym tematyce miejskiej są badania dyskursu tekstów hip-hopowych (Żmuda, 2014; Kurnicki, 2014), w których autorzy analizują teksty raperów i na ich podstawie konstruują obraz miasta, sposoby jego przedstawiania, a także szczególną rolę osiedla jako centrum raperskiego świata.

Wreszcie, osadzone w nurcie nauk społecznych jest przekrojowe badanie konfliktów przestrzenno-społecznych w Warszawie zrealizowane przez Waldemara Siemińskiego i Zofię Bidę-Wawryniuk (2017) na podstawie dyskursu prasowego. Miało ono na celu określenie liczby i typów konfliktów, ich dystrybucji przestrzennej i natężenia, a także roli poszczególnych aktorów (władzy publicznej, ruchów miejskich) w ich rozwiązywaniu oraz ocenę samego rozwiązania.

Wykonana na potrzeby niniejszego artykułu analiza literatury przedmiotu potwierdza nie tylko interdyscyplinarny charakter badań związanych z analizą dyskursu, ale i to, że sam dyskurs jest przez badaczy różnie postrzegany, będąc pojęciem wieloznacznym. Niekiedy analizy te polegają wyłącznie na zbadaniu tekstów lub wywiadów i określeniu wynikającego z nich przesłania. Czasem reprezentują szerszą perspektywę, włączając w badanie uczestników dyskursu lub/i nakreślając szerszy kontekst społeczny lub/i historyczny.

Jak dotąd najpełniejsze ramy metodologiczne odwołujące się wprost do krytycznej analizy dyskursu (KAD) i opierające się częściowo na metodologii Fairclougha (np. 1995) zostały zarysowane i wykorzystane w publikacji Jacka Gądeckiego (2009) poświęconej osiedlom grodzonym w Polsce w kontekście rodzącej się klasy średniej. Przeprowadzona przez autora analiza objęła identyfikację kontekstu dyskursu, propozycję typologii analizowanych tekstów, wskazanie typów dyskursów (informacyjny, opisowo-afirmacyjny, opisowo-krytyczny, krytyczno-problemowy), ustalenie zawartości tekstów, a także określenie uczestników dyskursu (firmy deweloperskie, architekci, naukowcy, samorządy, mieszkańcy) i zidentyfikowanie roli języka w tworzeniu konkretnych przekazów. Autor, badając teksty dotyczące osiedli grodzonych z lat 1994-2007, stawia też sobie za cel uchwycenie zmiany dyskursu w czasie (od fazy czysto informacyjnej, przez nacechowaną pozytywnie lub krytycznie, do fazy problematyzowania), a ponadto podejmuje próbę określenia tzw. kamieni milowych - tekstów i wydarzeń, które odegrały przełomową rolę w zaistnieniu zmiany. Ważnym elementem, odnoszącym się do szerszego kontekstu społecznego towarzyszącego dyskursowi, są też tzw. ramy (lęku i bezpieczeństwa, prestiżu oraz estetyczna i klasowa). 
O wpisaniu analizy w nurt krytyczny świadczy postawiony i zrealizowany cel pracy - ukazanie roli języka w kształtowaniu postaw mieszkaniowych, ale też polityki mieszkaniowej, czy nawet miejskiej jako takiej, nakreślenie nieoczywistych aspektów politycznych, kulturalnych i instytucjonalnych związanych ze zjawiskiem grodzonych osiedli.

\section{Metodyka badania, cel, pytania badawcze, przedmiot badania}

Publikacja Gądeckiego (2009) ze względu na całościowe podejście do kwestii analizy dyskursu stała się dla mnie ważnym punktem odniesienia przy konstruowaniu przedmiotu badania oraz podczas wyboru zastosowanych w nim narzędzi. Celem badania stała się natomiast próba uchwycenia obrazu wielkich osiedli mieszkaniowych w polskim pozanaukowym dyskursie publicznym, przy czym głównie interesowały mnie kwestie architektoniczne i urbanistyczne związane z tymi osiedlami. Szczegółowe pytania badawcze brzmiały: czy WOM są obecne w tym dyskursie (brak dyskursu byłby równie znaczący jak jego obecność); a jeśli tak, to w jaki sposób osiedla te są przedstawiane: jak są waloryzowane, jakie aspekty urbanistyczne i architektoniczne są przedmiotem dyskursu, jakie inne aspekty są poruszane w kontekście opisu blokowisk.

Za przedmiot analizy współczesnego polskiego dyskursu publicznego wybrałam najnowsze teksty pisane, które bezpośrednio lub pośrednio odnoszą się do tematu blokowisk. Badanie dotyczyło tekstów z jednego roku, takich, które powstały/ukazały się w 2017 r. - chodziło bowiem o uchwycenie jak najnowszego dyskursu publicznego na temat WOM. Inne założenie metodologiczne dotyczyło ograniczenia przestrzennego do osiedli wielkopłytowych leżących na terenie Warszawy. Stąd też jako źródła analizy dyskursu wybrałam: regionalny dodatek „Gazety Wyborczej” - „Gazetę Stołeczną”, blogi o tematyce warszawskiej, miejskiej, oraz teksty z oficjalnych płyt raperów warszawskich, które ukazały się w 2017 r. ${ }^{3}$ Analiza dyskursu, wpisując się w jej krytyczny nurt, objęła następujące elementy: identyfikację

${ }^{3}$ Hip-hop jako gatunek w dużej mierze koncentruje się na opisie przestrzeni miejskiej i życiu w miastach. W Polsce lat dziewięćdziesiątych XX w., gdy społeczeństwo podzieliło się na wygranych i przegranych transformacji, stał się ważnym, choć pozasystemowym głosem młodych ludzi (z tzw. kultury blokersów). W tamtym okresie powstało wiele utworów, które „działy się na osiedlach”, np. utwory grupy Molesta. Z tego powodu wydawało się interesujące zbadanie po latach tego dyskursu, który jako jedyny przed laty gloryfikował w pewnym sensie blokowiska (Żmuda, 2014; Kurnicki, 2014). 
uczestników dyskursu - określenie typu podmiotu, czyli kto i do kogo mówi; analizę zawartości dyskursu, czyli co się mówi; określenie typu dyskursu: informacyjny, afirmacyjny, krytyczny (posłużono się kategoriami Gądeckiego, 2009) oraz roli języka, czyli jak się mówi. Wyszukiwanymi frazami były: „,blokowisko”, „osiedle z wielkiej płyty”, „osiedle z prefabrykatów”, „wielka płyta”, ale także nazwy konkretnych wielkich osiedli warszawskich.

\section{Wyniki badania}

Jeśli chodzi o „Gazetę Stołeczną”, w wyniku przeszukania archiwum internetowego „Gazety Wyborczej” stwierdzono, że WOM pojawił się w 56 artykułach, tym samym potwierdzając obecność dyskursu w tekstach publikowanych w gazecie, która jest nadal najpopularniejszym dodatkiem regionalnym wśród warszawiaków. I choć frekwencja występowania tematu bloków i blokowiska nie jest zbyt częsta, jednak stale obecna na łamach tej gazety.

Podmiotami tworzącymi dyskurs są: stali dziennikarze zajmujący się tematyką miejską, osoby zawodowo związane z miastem i urbanistyką (socjologowie, architekci, przedstawiciele firmy budowlanej, pracownik Muzeum Warszawskiej Pragi), znani publicyści, artyści (np. Beata Chomątowska, Jerzy S. Majewski, Paweł Sołtys (Pablopavo)), znani w środowisku warszawskim aktywiści miejscy (np. Jan Mencwel z Miasto Jest Nasze, Krzysztof Śmietana z bloga Czerwony Autobus), a także mieszkańcy osiedli. Ciekawa jest nieobecność przedstawicieli samorządu gminnego, pracowników miejskich jednostek, a także administratorów i pracowników spółdzielni, które zarządzają sporą częścią bloków zbudowanych w technologii wielkiej płyty. Ogólnie można stwierdzić, że dyskurs na temat bloków i blokowisk często prowadzą osoby opiniotwócze i popularne wśród czytelników. Wydaje się, że w przypadku Warszawy dla recepcji bloków i blokowisk najważniejsze są wypowiedzi znanych w środowisku warszawskim publicystów, w tym varsavianisty Jerzego S. Majewskiego, który jest autorytetem w sprawach stolicy, oraz Beaty Chomątowskiej, autorki popularnych książek na temat architektury współczesnej.

Z przeprowadzonej analizy materiałów prasowych wynika, że w odniesieniu do WOM przeważa opis informacyjny. Najczęściej temat bloków występuje jako tło artykułów lub tekstów informacyjnych - jako ogólny element krajobrazu, miejsce opisywanego wydarzenia. Niejako dla ustalenia miejsca akcji pada jedno z wyszukiwanych określeń, w tym nazwa konkretnego osiedla. Można uznać te dyskursy za neutralne, choć wydaje się, że używane 
czasem w tekstach słowo „blokowisko” nadal jest nacechowane pejoratywnie. Drugim typem napotkanych tekstów w tej kategorii są artykuły, w których osiedla stanowią główny temat publikacji. Opisują szczegółowo historię osiedla, np. Iskry na Gocławiu czy Stegien, koncentrując się na aspektach architektonicznych, rozwiązaniach technologicznych, pomysłach urbanistycznych. Język tych tekstów również można uznać za neutralny, ponieważ brakuje w nich słownictwa czy konstrukcji gramatycznych nacechowanych emocjonalnie. Warto jednak zauważyć fakt cyklicznego opisywania historii osiedli wielkopłytowych - świadczy to bowiem o zainteresowaniu tą tematyką wśród twórców, ale i czytelników gazety. Tym samym blokowiska zostają niejako „odczarowane” - stają się tematem artykułów o Warszawie; z pozycji nieciekawych, szarych, odhumanizowanych osiedli awansują na pełnoprawną atrakcję turystyczną stolicy, zyskując indywidualne rysy. Można przyjąć, że takie ukazanie osiedli może przełożyć się na zmianę ich postrzegania przez odbiorców dyskursu.

Kolejnym pod względem częstotliwości występowania jest dyskurs nacechowany pozytywnie, co może dziwić w kontekście stereotypowego wyobrażenia na temat oceny bloków i blokowisk w dyskursie publicznym. Po pierwsze, pozytywnie oceniane są aspekty urbanistyczne i architektoniczne, w tym racjonalne założenia urbanistyczne osiedli, duża ilość przestrzeni i zieleni, dobra infrastruktura usługowa, dogodne połączenia komunikacyjne, trwała technologia prefabrykatów. W tym ujęciu osiedla wielkopłytowe zapewniają wysoką jakość życia. To ostatnie zagadnienie jest zaskakujące w świetle stereotypowego postrzegania blokowisk jako „gett”. Szczególnie ciekawe wydają się artykuły, w których osiedla wielkopłytowe zostają zestawione z osiedlami grodzonymi. Można postawić tezę roboczą, że te pierwsze zyskują w obliczu tych drugich. Wydaje się, że można by wiązać zauważalną zmianę nastawienia do blokowisk z coraz bardziej widoczną w dyskursie publicznym negatywną oceną osiedli grodzonych. W tym kontekście blokowiska są chwalone za niespotykany na nowych osiedlach porządek przestrzenny, duże odległości między blokami, zieleń, dobrą infrastrukturę komunikacyjną, brak kamer, ochroniarzy.

Po drugie, pozytywnie oceniane są bliskie relacje mieszkańców. W artykułach tego typu najczęściej jawią się one jako zmitologizowany świat przeszły, nostalgiczna opowieść o idyllicznej przeszłości. Są to wspomnienia mieszkańców, którzy opowiadają o osiedlach jako o świecie swojej młodości lub dzieciństwa. W dyskursie pozytywnie nacechowane są przede wszystkim aspekty urbanistyczne i przestrzenne osiedli, w których spędzało się wolny czas (np. lokalne jeziorko, górka, budka z zapiekankami, osiedlowy klub), 
jak i bliskie relacje społeczne. W jednym artykule (socjologa) pozytywnie został oceniony miks społeczny dawnych osiedli.

Najmniej z analizowanych tekstów cechuje krytyczna ocena bloków i blokowisk, przy czym nie tyle dotyczy ona czasów obecnych, ile funkcjonowania blokowisk w latach dziewięćdziesiątych. Krytyczny dyskurs odnosi się głównie do sytuacji społecznej osiedli wielkopłytowych okresu transformacji. WOM z tamtego okresu uważane były za miejsca niebezpieczne, przytłaczające, szare, gdzie przestrzeń publiczną zdominowali młodzi budzący strach ludzie (dresiarze). Osadzenie narracji w czasie przeszłym pozwala na wyprowadzenie wniosku, że ta ocena krytyczna nie dotyczy już obecnych osiedli.

Z kolei jeśli chodzi o blogi, to, po pierwsze, trzeba zauważyć, że ze 150 przebadanych blogów tylko 20 było aktywnych w 2017 r. i spełniało przyjęte kryteria, tzn. były to blogi o Warszawie, których autorzy głównie dokonywali wpisów. Z badania wykluczono fotoblogi, blogi specjalistyczne (poświęcone np. warszawskim restauracjom czy komunikacji miejskiej) i blogi zamknięte, tj. wymagające rejestracji. W sumie wyszukiwane słowa lub wyrażenia pojawiły się na zaledwie trzech blogach, w szesnastu wpisach. W związku z tym można stwierdzić, że obraz bloków i blokowisk z rzadka pojawia się na blogach poświęconych Warszawie, a więc że ten temat, niezależnie od ujęcia czy oceny, nie zajmuje autorów.

Podmiotami tworzącymi dyskurs są: przewodnicy miejscy, aktywiści miejscy, socjolog, antropolog kulturowy, fotograf, dziennikarze, anonimowi autorzy i autorki wpisów. Trudno ocenić, jak duży wpływ mogą wywierać pojawiające się na blogach dyskursy o blokowiskach. Ze zidentyfikowanych blogów wpływowym i opiniotwórczym w środowisku młodych warszawiaków jest Pańska Skórka (https://www.panskaskorka.com) - tworzona przez grupę dziennikarzy i aktywistów.

Mniej więcej w połowie tekstów przeważa dyskurs informacyjny. Pozostałe wpisy głównie zawierają pozytywną ocenę bloków i blokowisk. Afirmacyjny dyskurs, podobnie jak w przypadku artykułów z „Gazety Stołecznej”, odnosi się do aspektów przestrzennych i urbanistycznych osiedli, często w zestawieniu z deweloperskimi osiedlami ostatnich lat. Osiedla wielkopłytowe są cenione z powodu całościowego planowania, dużej ilości zieleni, wolnej przestrzeni, infrastruktury publicznej, bezpieczeństwa, dobrej komunikacji łączącej osiedla z centrum oraz dobrych relacji z innymi mieszkańcami. Ten typ dyskursu służy także do opisu osiedli jako zmitologizowanego, wyidealizowanego miejsca z okresu dzieciństwa. Krytyczny dyskurs dający negatywny obraz osiedli, podobnie jak w „Gazecie Stołecznej”, dotyczy sytuacji z lat dziewięćdziesiątych. 
Trzecią grupą badanych tekstów były utwory znajdujące się na legalnie wydanych płytach warszawskich raperów, które ukazały się w 2017 r. W sumie znaleziono i przeanalizowano 14 albumów za pomocą strony https:/genius.com (prezentującej teksty utworów muzycznych). Wyszukiwane frazy pojawiły się na 10 z 14 płyt, w sumie w 26 na 171 utworów. Wydaje się, że nie występowały aż tak często, jak można by zakładać ze względu na gatunek muzyczny, który jest mocno osadzony w kulturze blokowisk. Częściej odniesieniem przestrzennym było całe miasto postrzegane jako „dżungla miejska” lub zestaw miejscówek, w których można się zabawić lub pokazać.

Twórcami dyskursu są mieszkający w Warszawie raperzy urodzeni w latach siedemdziesiątych, osiemdziesiątych i dziewięćdziesiątych, którzy są znani głównie w środowisku słuchaczy rapu. Niektórzy z nich są również, a może obecnie nawet głównie, producentami muzycznymi i przedsiębiorcami. Wpływ tworzonego przez nich dyskursu będzie więc dotyczył odbiorców ich muzyki, która nadal cieszy się bardzo dużą popularnością.

Analiza tekstów warszawskich raperów - ze względu na to, że mamy do czynienia z kreacją artystyczną oraz określonymi wymogami samego gatunku (szerzej Miszczyński, 2014) - nie pozwala na proste przyporządkowanie ich do typów dyskursów, które udało się wyróżnić w przypadku analizy artykułów z „Gazety Stołecznej” i wpisów na blogach. O ile łatwo można wskazać miejsce/rolę bloków czy blokowisk w utworach, o tyle trudniej jednoznacznie ocenić, w jaki typ dyskursu się one wpisują. Wydaje się, że ogólnie można wyróżnić dwa typy dyskursu: afirmacyjny i krytyczny, a tym samym, paradoksalnie, obraz osiedli i blokowisk w utworach raperów można uznać jednocześnie za pozytywną i krytyczną ocenę tych przestrzeni. Pierwszy typ należałoby przypisać do utworów, w których blok/blokowisko występuje jako środowisko społeczne twórców hip-hopu - miejsce tworzenia muzyki, codziennego życia, dzielenia doświadczeń z rówieśnikami. Osiedle jest oazą bezpieczeństwa, „swoim” miejscem, także wtedy, gdy opowiada się o nim w czasie przeszłym - z pozycji osoby w średnim wieku. Zgodnie z tą narracją osiedle jest ważnym miejscem powstania i rozwoju rapu oraz zdobywania osobistych doświadczeń, które pozwoliły na ukształtowanie się artyście.

Drugi typ dyskursu dotyczy utworów, w których blokowiska są postrzegane jako miejsca wykluczenia społecznego. W tych utworach osiedla są przestrzenią osób zmarginalizowanych, ze środowisk kryminogennych, żyjących w gorszych dzielnicach i pozbawionych perspektyw na zmianę przy tego typu dyskursie można więc mówić o odniesieniach klasowych, 
choć nie wybrzmiewają one wprost z utworów. Jednocześnie te krytyczne oceny można uznać za zmitologizowany obraz osiedli wynikający z cech samego gatunku muzycznego. Zaskakujący wydaje się brak głębszej refleksji na temat blokowisk. W końcu gatunek ten żyje, czerpie z nich siły. Nie ma porównań między obecnym życiem „na osiedlu” i w „lepszych częściach miastach”, np. osiedlach grodzonych - te ostatnie wcale nie występują w utworach. Można postawić pytanie, czy obraz blokowisk we współczesnych utworach raperów nie jest kalką obrazu tych osiedli z lat dziewięćdziesiątych - a jedyne zmiany, jakie na nich zaszły, dotyczą ludzi. Osiedle, blok są miejscem odniesienia i przeżywania świata, ale zdaje się - niczym specjalnie więcej i nieco przypominają figurę retoryczną. Ważniejsze na pewno jest doświadczenie zdobyte/zdobywane na blokowiskach wspólnie z grupą rówieśniczą - bo ono stanowi o autentyczności artysty. Z kolei niezbyt duża liczba utworów, które w ten czy inny sposób porusza temat blokowisk i osiedla, może świadczyć też o tym, że obecnie raperzy „wypłynęli na szersze wody”, że ich środowiskiem stało się już miasto jako całość.

\section{Podsumowanie}

Przeprowadzona analiza dyskursu, obejmująca artykuły prasowe, wpisy na blogach i utwory hip-hopowe, wykazała, że bloki i blokowiska są obecne w pozanaukowym dyskursie publicznym. W przypadku dyskursu wartościującego mamy do czynienia przede wszystkim z dyskursem afirmacyjnym, w tym z pozytywną oceną osiedli wielkopłytowych w zestawieniu z krytyczną oceną osiedli grodzonych. Waloryzowane są zarówno aspekty urbanistyczne i architektoniczne WOM, jak i relacje społeczne. Warto jednak zauważyć, że jako temat dyskursu nie pojawiają się przestrzenie wewnątrzblokowe - przestrzenie wspólne czy indywidualne mieszkania, sposób ich rozplanowania, jakość użytych materiałów, jakość życia w osiedlowym mieszkaniu. Pozytywne oceny bloków i blokowisk często są formułowane przez osoby opiniotwórcze - znanych dziennikarzy, pisarzy, aktywistów i artystów, co wywiera wpływ na zmianę opinii o blokach i blokowiskach u odbiorców dyskursu, czytelników artykułów i wpisów. Nieco inaczej wypada ocenić dyskurs w utworach hip-hopowych, w których jest on zawsze nacechowany, ale zarówno afirmacyjnie, jak i krytycznie, i którego odbiorcami, ze względu na pozamainstreamowy charakter tej muzyki, są całkiem liczni fani gatunku. 
Wydaje się, że na podstawie przeprowadzonej analizy można wstępnie wysunąć tezę, iż właśnie następuje zmiana paradygmatu postrzegania wielkich osiedli mieszkaniowych. W wyniku tego wniosku pokusiłam się w nawiązaniu do Gądeckiego (2009) - o zidentyfikowanie kamieni milowych tej zmiany. Wydaje się, że mogły się do niej przyczynić następujące znane i szeroko dyskutowane publikacje: Przewodnik po blokowiskach warszawskich Jarosława Trybusia (2011), książki Filipa Springera: Źle urodzone. Reportaże o architekturze PRL (2012), 13 pięter (2015), Miasto Archipelag. Polska mniejszych miast (2016), a także wpływowy w środowiskach aktywistów miejskich i profesjonalistów zajmujących się miejską tematyką film dokumentalny Bloki w reżyserii Konrada Królikowskiego (2017). Przeprowadzone badanie wpisuje się w ramy metodologiczne analizy dyskursu oraz, choć nie w pełni, w jego nurt krytyczny - pomija bowiem kwestię dyskursu jako elementu szeroko rozumianej władzy. Niewątpliwie, ciekawe wydaje się pogłębienie tego wymiaru przez zbadanie dyskursu o WOM w relacji do napięć między mieszkańcami blokowisk i osiedli grodzonych.

\section{Literatura}

Biskupska, K. (2018). „Miasto to jak mieszkanie”. Nasze. Powojenne strategie oswajania miast Ziem Zachodnich i Północnych na przykładzie Wrocławia. Miscellanea Anthropologica et Sociologica, 19(4), 129-148.

Bukłaha, Z. (2017). Czego Warszawa nie wie?, Gazeta Stołeczna, 14.07.2017, 12.

Chilton, P. (2008). Brakujące ogniwo KAD: moduły, amalgamy i instynkt krytyczny. W: A. Duszak, N. Fairclough (red.), Krytyczna analiza dyskursu (ss. 61-102). Kraków: Universitas.

Chomątowska, B. (2017). Niech „blokowisko” zostanie w latach 90. Gazeta Stołeczna, 30.05.2017, 2.

Chomątowska, B. (2018). Betonia. Dom dla każdego. Wołowiec: Wydawnictwo Czarne.

Dijk, T.A., van. (1993). Principles of critical discourse analysis, Discourse \& Society, 2, 249-283.

Duda, B. (2015). Dyskursywne i tekstowe reprezentacje współczesnej przestrzeni miejskiej, Katowice: Uniwersytet Śląski.

Duda, B. (2018). Miasto w świecie dyskursów. Katowice: Wydawnictwo Uniwersytetu Śląskiego.

Duszak, A. (1998). Tekst, dyskurs, komunikacja międzykulturowa. Warszawa: Wydawnictwo Naukowe PWN.

Duszak, A., Fairclough, N. (red.). (2008). Krytyczna analiza dyskursu. Interdyscyplinarne podejście do komunikacji społecznej. Kraków: Universitas.

Duszak, A., Kowalski, G. (red.). (2013). Systemowo-funkcjonalna analiza dyskursu. Kraków: Universitas. 
Dymitrow, M. (2015). Dyskurs degradacji miast w Polsce: próba dekonstrukcji. W: R. Krzysztofik, M. Dymitrow (red.), Miasta zdegradowane i restytuowane w Polsce. Geneza, rozwój, problemy (ss. 355-361). Gothenburg. University of Gothenburg.

Fairclough, N. (1989). Language and Power. London: Longman.

Fairclough, N. (1992). Discourse and Social Change. Cambridge: Polity Press.

Fairclough, N. (1995). Critical Discourse Analysis: The Critical Study of Language. New York: Longman.

Fairclough, N., Duszak, A. (2008). Krytyczna analiza dyskursu - nowy obszar badawczy dla lingwistyki i nauk społecznych. W: A. Duszak, N. Fairclough (red.), Krytyczna analiza dyskursu (ss. 7-32). Kraków: Universitas.

Foucault, M. (1971). L'Ordre du discour. Paris: Gallimard.

Foucault, M. (2002). Porzq̨dek dyskursu. Wykład inauguracyjny wygłoszony w College de France 2 grudnia 1970 roku, przeł. M. Kozłowski. Gdańsk: Słowo/obraz terytoria.

Fowler, R., Hodge, B., Kress, G., Trew, T. (1979). Language and Control. London: Routledge.

Gądecki, J. (2009). Za murami. Osiedla grodzone w Polsce - analiza dyskursu. Toruń: Wydawnictwo Naukowe UMK.

Grabkowska, M. (2017). Przestrzeń miasta postsocjalistycznego jako dobro wspólne. Przegląd koncepcji teoretycznych. Prace Geograficzne, 149, 33-52.

Grabkowska, M. (2018). Urban space as a commons in print media discourse in Poland after 1989. Cities, 71, 22-29.

Graham, P. (2008). KAD a wartości: interdyscyplinarność jako zwrot w kierunku podejścia krytycznego. W: A. Duszak, N. Fairclough (red.), Krytyczna analiza dyskursu (ss. 33-59). Kraków: Universitas.

Gumperz, J.J. (1982). Discourse Strategies. Cambridge: Cambridge University Press.

Halliday, M.A.K. (1978). Language as Social Semiotic: The Social Interpretation of Language and Meaning. London: Edward Arnold.

Instytut Techniki Budowlanej. (2019). Budownictwo wielkopłytowe - Raport o stanie technicznym. Warszawa. https://budowlaneabc.gov.pl/budownictwo-wielkoplytoweraport-o-stanie-technicznym, dostęp: 15.07.2019.

Jańczak, J. (2013). Miasta (trans)graniczne jako uczestnicy procesu integracji europejskiej. TEKA of Political Science and International Relationships, 8, 53-63.

Korczyńska-Partyka, D. (2018). Narracje miejskie w literaturze polskiej po 1989 roku. Pamięć, przestrzeń, dyskurs. Gdańsk: Wydawnictwo Uniwersytetu Gdańskiego.

Królikowski, K. (reż.). (2017). Bloki, film dokumentalny, barwny, 57 min. Polska. Media Dizajn.

Kurnicki, K. (2014). „Dziś w moim mieście”: społeczna i polityczna przestrzeń codzienna w hip-hopie. W: M. Miszczyński (red.), Hip-hop w Polsce: od blokowisk do kultury popularnej (ss. 144-164). Warszawa: Wydawnictwa Uniwersytetu Warszawskiego.

Laclau, E., Mouffe, Ch. (2007). Hegemonia i strategia socjalistyczna, przeł. S. Królak. Wrocław: Wydawnictwo Naukowe Dolnośląskiej Szkoły Wyższej.

Lipiński, J.S. (2015). Dyskurs metropolitalny na przykładzie Trójmiasta. Biuletyn Komitetu Przestrzennego Zagospodarowania Kraju PAN, 259, 100-124.

Marzec, W. (2011). Poststrukturalistyczna teoria dyskursu i empiryczne badania społeczne. Praktyka Teoretyczna, 4, 185-198. 
Miszczyński, M. (red.). (2014). Hip-hop w Polsce: od blokowisk do kultury popularnej. Warszawa: Wydawnictwa Uniwersytetu Warszawskiego.

Nijakowski, L. (2006). Domeny symboliczne. Konflikty narodowe i etniczne w wymiarze symbolicznym. Warszawa: Wydawnictwo Naukowe Scholar.

Schiffrin, D. (1994). Approaches to Discourse. Blackwell Textbooks in Linguistics, Oxford: Blackwell.

Siemiński, W., Bida-Wawryniuk, Z. (2017). Konflikty społeczno-przestrzenne w Warszawie w latach 2013-2014, prezentacja badania w ramach cyklu seminariów Euroreg Centrum Europejskich Studiów Regionalnych i Lokalnych UW. http://www.euroreg. uw.edu.pl/dane/web_euroreg_seminary_files/1059/siemiski_bida-wawryniuk_konflikty_spoeczno-przestrzenne_w_warszawie_23.11.17.pdf, dostęp: 15.07.2019.

Sinclair, J.M., Coulthard, R.M. (1975). Towards an Analysis of Discourse: The English Used by Teachers and Pupils. London: Oxford University Press.

Słodczyk J. (2012). Historia planowania i budowy miast. Opole: Wydawnictwo Uniwersytetu Opolskiego.

Springer, F. (2012). Źle urodzone. Reportaże o architekturze PRL. Kraków: Karakter.

Springer, F. (2015). 13 pięter. Wołowiec: Wydawnictwo Czarne.

Springer, F. (2016). Miasto Archipelag. Polska mniejszych miast. Kraków: Karakter.

Synowiec, A. (2013). W stronę analizy tekstu - wprowadzenie do teorii dyskursu. Zeszyty Naukowe Politechniki Ślq̨skiej, 65, 383-395.

Szacki, J. (2012). Historia myśli socjologicznej. Wydanie nowe. Warszawa: Wydawnictwo Naukowe PWN.

Szafrańska, E. (2016). Wielkie osiedla mieszkaniowe w mieście postsocjalistycznym. Geneza, rozwój, przemiany, percepcja. Łódź: Wydawnictwo Uniwersytetu Łódzkiego.

Trybuś, J. (2011). Przewodnik po blokowiskach warszawskich. Warszawa: Muzeum Powstania Warszawskiego.

Węcławowicz, G. (2007). Geografia społeczna miast. Warszawa: Wydawnictwo Naukowe PWN.

Żmuda, M. (2014). Pasaże tekstowe w polskim hip-hopie. Analiza opisów przestrzeni miejskiej w wybranych tekstach rapowych. Konteksty Kultury, 2(11), 143-156. 